\title{
In vitro and in vivo antiproliferative activity of Calotropis procera stem extracts
}

\author{
HEMERSON I.F. MAGAlHÃes ${ }^{1}$, PAUlO M.P. FERREIRA ${ }^{2}$, ERALdO S. MOURA ${ }^{3}$, \\ MÁRCIA R. TORRES ${ }^{1}$, ANA P.N.N. ALVES ${ }^{4}$, OTÍLIA D.L. PESSOA ${ }^{5}$, LETÍCIA V. COSTA-LOTUFO ${ }^{1}$, \\ MANOEL O. MORAES ${ }^{1}$ and CLÁUDIA PESSOA ${ }^{1}$ \\ ${ }^{1}$ Departamento de Fisiologia e Farmacologia, Faculdade de Medicina, Universidade Federal do Ceará \\ Campus do Porangabussu, Rua Cel. Nunes de Melo, 1127, 60430-270 Fortaleza, CE, Brasil \\ ${ }^{2}$ Campus Senador Helvídio Nunes de Barros, Universidade Federal do Piauí \\ Rua Cícero Eduardo, s/n, 64600-000 Picos, PI, Brasil \\ ${ }^{3}$ Departamento de Cirurgia, Faculdade de Medicina, Universidade Federal do Ceará, \\ Campus do Porangabussu, Rua Prof. Costa Mendes, 1608, 60416-160 Fotaleza, CE, Brasil \\ ${ }^{4}$ Departamento de Clínica Odontológica, Universidade Federal do Ceará \\ Rua Monsenhor Furtado, s/n, 60430-270 Fortaleza, CE, Brasil \\ ${ }^{5}$ Departamento de Química Orgânica e Inorgânica, Universidade Federal do Ceará \\ Av. Mister Hall, s/n, 60455-970 Fortaleza, CE, Brasil \\ Manuscript received on March 30, 2009; accepted for publication on June 18, 2009
}

\begin{abstract}
The cytotoxic potential of stem organic extracts from Calotropis procera (Asclepiadaceae) was firstly evaluated against cancer cell lines by MTT assay. Subsequently, samples considered cytotoxic were tested for antimitotic activity on sea urchin egg development and for in vivo antiproliferative activity in mice bearing Sarcoma 180 tumor. Among the five extracts (hexane, dichloromethane, ethyl acetate, acetone and methanol), ethyl acetate and acetone extracts displayed higher cytotoxic potential against tumor cells, with $\mathrm{IC}_{50}$ ranging from 0.8 to $4.4 \mu \mathrm{g} / \mathrm{mL}$, while methanolic extract was weakly cytotoxic. Cytotoxic extracts also exhibited cell division inhibition capacity by antimitotic assay, revealing $\mathrm{IC}_{50}$ values lower than $5 \mu \mathrm{g} / \mathrm{mL}$. In the in vivo antitumor assessments, ethyl acetate- and acetone-treated animals showed tumor growth inhibition ratios of 64.3 and $53.1 \%$, respectively, with reversible toxic effects on liver and kidneys. Further studies are in progress in order to identify $C$. procera cytotoxic compound(s) and to understand the mechanism of action responsible for this tumor-decreasing potential.
\end{abstract}

Key words: antimitotic, antiproliferative, Calotropis procera, Sarcoma 180 tumor, stem extracts.

\section{INTRODUCTION}

Calotropis procera Aiton, 1811 (Gentianales: Asclepiadaceae) is a perene Asian shrub called "Ushar", being very common in adverse climate conditions and poor soils explaining its good adaptation to the Northeast Brazil, where it was introduced at the beginning of the century XIX, spreading within different biomes such as "Caatinga" and "Cerrado" (Kissmann and Groth 1999, Lorenzi and Matos 2002).

In Brazil, C. procera is popularly known as “algodão

Correspondence to: Dr. Hemerson Iury Ferreira Magalhães

E-mail: hemersoniury@yahoo.com.br de seda", "leiteiro", "queimadeira" and "ciúme" (Kissmann and Groth 1999, Lorenzi and Matos 2002). Different parts of this tree have been used to treat and prevent diseases. In India, the leaves are prepared to ease pain from a variety of conditions (Satyavati et al. 1976). They possess anthelmintic (Iqbal et al. 2005), analgesic, antipyretic, antispasmodic (Mascolo et al. 1988, Dewan et al. 2000) and anti-inflammatory (Kumar and Basu 1994) properties. It is also notorious their antimalaric activity against Plasmodium falciparum (Sharma and Sharma 2000) and hepatoprotective action by the glutathione reduced decreasing prevention, an effect proba- 
bly reached due to flavonoids with antioxidant potentiality similar to vitamin C (Ahmed et al. 2003, Setty et al. 2007, Ferreira et al. 2008).

The latex found in the aerial parts (young leaves, predominantly) is utilized to treat diarrhea (Satyavati et al. 1976), possibly due to its desensitization of the gastrointestinal smooth muscle cells (Kumar and Shivkar 2004) and antimicrobial action (Jain et al. 1996). Moreover, latex possess biological activity against the coccidian protozoa Eimeria ovinoidalis (Mahmoud et al. 2001) and Aedes aegypti larvae (Ramos et al. 2006), protection against hyperglycemia induced by alloxan (Roy et al. 2005) and anti-inflammatory (Alencar et al. 2004) effects. Root methanolic extracts simulates oestrogenic actions, altering uterine endometrial and interfering on the blastocyst implantation (Kamath and Rana 2002), while stem bark extracts reduces bronchial inflammation, showing antitussigene activity by oral administration (Dieye et al. 1993). In this work, the great pharmacological potential of $C$. procera was evaluated aiming to study the in vitro cytotoxicity of stem extracts and their in vivo antitumor capacity on mice transplanted with Sarcoma 180 cells.

\section{MATERIALS AND METHODS}

\section{Plant Material And Extract Preparation}

Calotropis procera samples were collected in Sobral, Ceará, Brazil. A voucher specimen (34.706) was authenticated by Dr. Edson de Paula Nunes and deposited at Prisco Bezerra Herbarium (EAC), Department of Biology of Universidade Federal do Ceará, Brazil.

Stem samples $(1000.0 \mathrm{~g})$ were firstly grounded to a fine powder, weighed and subjected to successive extractions $(4 \times)$ in $100 \%$ ethanol with a sample mass to solvent volume proportion of 1:5 at room temperature $\left(25^{\circ} \mathrm{C}\right)$. Then, the material was concentrated under pressure until turn out a viscous residue. Afterwards, the ethanolic extract was partitioned using growing polarity organic solvents: hexane, dichloromethane, ethyl acetate, acetone and methanol. Each extraction procedure was performed under shaking for $24 \mathrm{~h}$. The extracts were concentrated in a rotary vacuum evaporator and dissolved in sterile pure dimethylsulfoxide (DMSO, Sigma Aldrich) to stock solutions of $50 \mathrm{mg} / \mathrm{mL}$.
ANIMALS

Adult Swiss mice (Mus musculus Linnaeus, 1758) were obtained from the animal facilities of Universidade Federal do Ceará. They were kept in cages (ALESCO, São Paulo) under standard conditions of light $(12 \mathrm{~h}$ with alternative day and night cycles) and temperature (25 \pm $1{ }^{\circ} \mathrm{C}$ ), and were housed with access to commercial rodent stock diet (Purina, São Paulo, Brazil) and water ad libitum. The investigational protocol was approved by the local Ethical Committee in Animal Research at Universidade Federal do Ceará (Process No. 102/2007), and is in accordance with International Standard on the care and use of experimental animals (EEC Directive of 1986, 86/609/EEC).

Adult sea urchins of the Lytechinus variegates Lamarck, 1816 (Echinoidea: Toxopneustidae) species were collected at Pecém beach, northeastern coast of Ceará, Brazil. The urchins were maintained under standard laboratory conditions until the beginning of the experiments.

\section{MTT ASSAY}

The cytotoxicity against the tumor cell lines HL-60, CEM (human leukemia), HCT-8 (human colon cancer) and B-16/F10 (murine melanoma) was determined by MTT assay (Mosmann 1983), which analyzes the ability of living cells to reduce the yellow dye 3-(4,5-dimethyl-2-thiazolyl)-2,5-diphenyl-2 $H$-tetrazolium bromide (MTT) to a purple formazan product. All lines were maintained in RPMI 1640 medium supplemented with $10 \%$ fetal bovine serum, $2 \mathrm{mM}$ glutamine, $100 \mathrm{U} / \mathrm{mL}$ penincillin and $100 \mu \mathrm{g} / \mathrm{mL}$ streptomycin, at $37^{\circ} \mathrm{C}$ with $5 \% \mathrm{CO}_{2}$. Briefly, cells were plated in 96 well plates $\left(0.7 \times 10^{5}\right.$ cells/well for adherent cells and $0.3 \times 10^{5}$ cells/well for suspended cells) and incubated to allow cell adhesion. Twenty-four hours later, stem extracts (hexane, dichloromethane, ethyl acetate, acetone and methanol) were added to each well $(0.39-25 \mu \mathrm{g} / \mathrm{mL})$. After $72 \mathrm{~h}$ of incubation, the supernatant was replaced by fresh medium containing 10\% MTT. The formazan product was dissolved in DMSO to measure absorbance at $595 \mathrm{~nm}$ (DTX-880, Beckman Coulter). Doxorubicin (Sigma Aldrich) was used as positive control (0.009$5 \mu \mathrm{g} / \mathrm{mL})$. 


\section{Antimitotic Assay}

The antimitotic assay was performed in 24-well plates according with Moreira et al. (2007). Gamete elimination from L. variegatus was induced by injecting $3.0 \mathrm{~mL}$ of $0.5 \mathrm{M} \mathrm{KCl}$ into the urchin's coelomic cavity via the periostomial membrane. Concentrated sperm was collected with a Pasteur pipette and preserved under low temperature until the fertilization. Each well received $1 \mathrm{~mL}$ of fertilized egg suspension and extracts (ethyl acetate, acetone and methanol) were added immediately after fertilization (within $2 \mathrm{~min})(0.1,1,5$ and $10 \mu \mathrm{g} / \mathrm{mL})$. Doxorubicin $(0.3 \mu \mathrm{g} / \mathrm{mL})$ and $1.6 \%$ DMSO were used as positive and negative controls, respectively. Plates were then shaken in a constant temperature water bath at $26 \pm 2^{\circ} \mathrm{C}$. At appropriate times, aliquots of $100 \mu \mathrm{L}$ were fixed with $10 \%$ formaldehyde to obtain first and third cleavages and blastulae. One hundred eggs or embryos per well were counted in order to calculate $\mathrm{IC}_{50}$ values.

\section{In vivo ANTITUMOR EVALUATION}

Fifty healthy male mice (M. musculus) weighing 23$26 \mathrm{~g}$ were subcutaneously implanted with nine-day-old Sarcoma 180 ascites tumor cells $\left(2 \times 10^{6}\right.$ cells $\left./ 0.5 \mathrm{~mL}\right)$ into the left hind groin of the mice. On the next day, they were randomly separated into five groups $(n=10$ each) to receive stem extracts (ethyl acetate, acetone and methanol dissolved in $0.9 \%$ saline) at the dose of $250 \mathrm{mg} / \mathrm{kg} /$ day. In contrast, negative and positive controls received saline and $5-\mathrm{FU}(50 \mathrm{mg} / \mathrm{kg} / \mathrm{day})$, respectively, all administered intraperitoneally for 7 days.

On day 8 , mice were sacrificed by cervical dislocation and their organs (kidneys, spleens and livers) and tumors were dissected out, grossly examined for size, color changes and hemorrhage, weighed and preserved in $10 \%$ formaldehyde solution. The inhibition ratio of tumor growth $(\%)$ was calculated by the following formula: inhibition ratio $(\%)=[(A-B) / A] \times 100$, where $A$ is the average tumor weight of the negative control, and $B$ is the tumor weight of the treated group. To examine morphological changes by light microscopy (Olympus, Tokyo, Japan), small pieces of organs and tumors were processed, embedded in paraffin and 3-5 $\mu \mathrm{m}$ thick sections were prepared and stained with hematoxylineosin.

\section{StATistical ANALYSis}

For cytotoxicity assays, the $\mathrm{IC}_{50}$ values and their $95 \%$ confidence intervals were obtained by nonlinear regression using the Graphpad program (Intuitive Software for Science, San Diego, CA). In order to determine differences among the treatments, data (mean \pm standard error mean) were compared by one-way analysis of variance (ANOVA) followed by Newman-Keuls test $(\mathrm{P}<0.01)$.

\section{RESULTS AND DISCUSSION}

Researches for antineoplasic compounds have demonstrated the great pharmacological relevance of the plant extracts (Cragg and Newman 2005, Costa et al. 2008, Buriol et al. 2009). At the last decades, C. procera received special attention, with lots of publications describing the biological activities of molecules and aqueous and organic extracts obtained from its distinct tissues (Jain et al. 1996, Kamath and Rana 2002, Ahmed et al. 2003, Iqbal et al. 2005, Ramos et al. 2006, Setty et al. 2007).

In the present work, we firstly determined the cytotoxic activity of organic extracts from $C$. procera stem using the MTT assay. According to the American National Cancer Institute, the $\mathrm{IC}_{50}$ limit to consider a promising crude extract for further purification is lower than $30 \mu \mathrm{g} / \mathrm{mL}$ (Suffness and Pezzuto 1990). Among the five extracts, ethyl acetate and acetone showed higher cytotoxic potential against tumor cells, with $\mathrm{IC}_{50}$ ranging from 0.8 to $4.4 \mu \mathrm{g} / \mathrm{mL}$ for colon (HCT-8) and melanoma (B-16) cells, respectively (Table I). Methanolic extract was weakly cytotoxic, despite the fact that it demonstrate moderately good activity on CEM line $\left[\mathrm{IC}_{50}\right.$ value of $2.8(2.1-4.1) \mu \mathrm{g} / \mathrm{mL}]$.

Previously, some reports showed that different parts of the plant exhibit cytotoxicity on cancer cells (Smit et al. 1995, Van Quaquebeke et al. 2005, Oliveira et al. 2007). Van Quaquebeke et al. (2005) isolated a natural cardiotonic steroid from the methanolic extract of $C$. procera root barks called $2^{\prime \prime}$-oxovoruscharin and developed a new hemisynthetic cardenolide derivative named UNBS1450 which display in vitro antiproliferative action comparable to taxol, while the latex shows cytotoxicity corroborated by morphological alterations in leukemia cells, such as chromatin condensation, DNA 
TABLE I

Cytotoxic activity of extracts obtained from Calotropis procera stem on tumor cell lines after $72 \mathrm{~h}$ of exposure.

\begin{tabular}{c|c|c|c|c|c}
\hline \multirow{2}{*}{ Substance } & \multirow{2}{*}{ Yield (\%) } & \multicolumn{4}{|c}{ Cell line } \\
\cline { 3 - 6 } & & \multicolumn{4}{|c}{$\mathrm{IC}_{50}(\mu \mathrm{g} / \mathrm{mL})^{*}$} \\
\cline { 3 - 6 } & & HL-60 & CEM & B-16/F10 & HCT-8 \\
\hline Hexane & 5.3 & $>25$ & $>25$ & $>25$ & $>25$ \\
\hline Dichloromethane & 22.7 & $>25$ & $>25$ & $>25$ & $>25$ \\
\hline \multirow{2}{*}{ Ethyl acetate } & 11.6 & 1.6 & 1.4 & 2.0 & 2.5 \\
\cline { 2 - 6 } & & $1.4-1.9$ & $1.1-3.8$ & $1.0-3.9$ & $2.3-2.6$ \\
\hline \multirow{2}{*}{ Acetone } & 10.4 & 2.1 & 1.4 & 4.4 & 0.8 \\
\cline { 2 - 6 } & & $2.1-2.2$ & $1.3-2.8$ & $2.1-9.0$ & $0.6-1.0$ \\
\hline \multirow{2}{*}{ Methanol } & 50.0 & 8.2 & 2.8 & $>25$ & 10.2 \\
\cline { 2 - 6 } & & $5.4-12.4$ & $2.1-4.1$ & & $7.2-14.2$ \\
\hline \multirow{2}{*}{ Doxorubicin } & - & 0.02 & 0.02 & 0.002 & 0.01 \\
\cline { 2 - 6 } & & $0.01-0.02$ & $0.02-0.03$ & $0.001-0.003$ & $0.01-0.02$ \\
\hline
\end{tabular}

*Data are presented as $\mathrm{IC}_{50}$ values and $95 \%$ confidence intervals for human leukemia (HL-60, CEM), murine melanoma (B-16/F10), and human colon cancer (HCT-8) cells. Experiments were performed in triplicate.

fragmentation and cell volume reduction (Choedon et al. 2006, Oliveira et al. 2007). It is established that cardiotonic steroid glycosides (bufalin and digoxin, for instance) are capable to kill cancer cells through the activation of apoptotic pathways (McConkey et al. 2000, Kurosawa et al. 2001). On the other hand, additional and recent investigations propose autophagy as a probable kind of cell death caused by UNBS1450 in human glioblastoma lines (Lefranc et al. 2008). Autophagy is a singular self-destructive process in which injured, unnecessary or old parts of the cells, as mitochondria and endoplasmic reticulum, are degraded by enzymatic activity within lysossomes (Maiuri et al. 2007).

Sea urchin egg development shows some peculiarities that allows us to suggest how antimitotic substances act. Acetone, ethyl acetate and methanol extracts inhibited the division of sea urchin eggs since the first cleavage in a concentration-dependent way, revealing $\mathrm{IC}_{50}$ values lower than $5 \mu \mathrm{g} / \mathrm{mL}$ (Table II). The inhibition at the first cleavage is related to DNA and/or protein synthesis or microtubule assembly, given that RNA synthesis is very slow or absent after fertilization. At this time, the rapid increasing in the rate of protein synthesis is largely due to the recruitment of maternal mRNA into polysomes (Brandhorst 1985). On the other hand, when a substance blocks microtubule assembly, clear spots corresponding to nucleus duplication can be observed in the cytoplasm. Since zygotes treated with the extracts exhibited homogeneous cytoplasm, this process appears not to have been affected (Jacobs and Wilson 1986). So, the stem organic extracts acetone, ethyl acetate and methanol may affect DNA and/or protein synthesis, confirming their in vitro antiproliferative activity showed by MTT assay.

TABLE II

Inhibition of cell division of Calotropis procera stem extracts on embryos of the sea urchin Lytechinus variegatus on the first and third cleavage and blastulae stages.

\begin{tabular}{c|c|c|c}
\hline \multirow{2}{*}{ Substance } & \multicolumn{3}{|c}{$\mathrm{IC}_{50}(\mu \mathrm{g} / \mathrm{mL})^{*}$} \\
\cline { 2 - 4 } & $\begin{array}{c}\text { First } \\
\text { cleavage }\end{array}$ & $\begin{array}{c}\text { Third } \\
\text { cleavage }\end{array}$ & Blastulae \\
\hline \multirow{2}{*}{ Ethyl acetate } & 3.2 & 2.0 & 1.1 \\
\cline { 2 - 4 } & $2.7-3.7$ & $1.5-2.7$ & $1.1-1.2$ \\
\hline \multirow{2}{*}{ Acetone } & 3.7 & 2.7 & 3.5 \\
\cline { 2 - 4 } & $2.5-5.5$ & $1.2-3.6$ & $1.5-8.0$ \\
\hline \multirow{2}{*}{ Methanol } & 4.1 & 3.7 & 4.7 \\
\cline { 2 - 4 } & $3.7-4.4$ & $3.3-4.2$ & $4.1-5.5$ \\
\hline \multirow{2}{*}{ Doxorubicin } & 6.3 & 0.3 & 0.5 \\
\cline { 2 - 4 } & $4.3-9.1$ & $0.2-0.7$ & $0.3-1.0$ \\
\hline
\end{tabular}

*Data are presented as $\mathrm{IC}_{50}$ values and $95 \%$ confidence intervals for sea urchin eggs. Doxorubicin was used as positive control. Experiments were performed in duplicate. 
TABLE III

Effects of the Calotropis procera stem extracts on mice transplanted with Sarcoma 180 cells.

\begin{tabular}{|c|c|c|c|c|c|c|c|}
\hline \multirow{2}{*}{ Group } & \multirow{2}{*}{$\begin{array}{c}\text { Dose } \\
(\mathrm{mg} / \mathrm{kg} / \text { day })\end{array}$} & \multirow{2}{*}{$\begin{array}{c}\text { Animal } \\
\text { weight }(g)\end{array}$} & Liver & Kidneys & Spleen & \multirow{2}{*}{ Tumor (g) } & \multirow{2}{*}{$\begin{array}{c}\text { Tumor } \\
\text { inhibition (\%) }\end{array}$} \\
\hline & & & \multicolumn{3}{|c|}{$\mathrm{g} / 100 \mathrm{~g}$ body weight } & & \\
\hline Control & - & $30.00 \pm 0.50$ & $5.94 \pm 0.21$ & $1.43 \pm 0.07$ & $0.69 \pm 0.05$ & $3.25 \pm 0.47$ & - \\
\hline $5-\mathrm{FU}$ & 50 & $24.60 \pm 0.40^{\mathrm{a}}$ & $4.86 \pm 0.27$ & $1.28 \pm 0.03$ & $0.22 \pm 0.01^{\mathrm{a}}$ & $0.11 \pm 0.05^{\mathrm{a}}$ & 96.5 \\
\hline Ethyl acetate & 250 & $29.00 \pm 0.94$ & $4.93 \pm 0.09$ & $1.38 \pm 0.02$ & $0.46 \pm 0.03$ & $1.40 \pm 0.35^{\mathrm{a}}$ & 64.3 \\
\hline Acetone & 250 & $29.38 \pm 0.82$ & $5.20 \pm 0.16$ & $1.50 \pm 0.06$ & $0.49 \pm 0.03$ & $1.34 \pm 0.22^{\mathrm{a}}$ & 53.1 \\
\hline Methanol & 250 & $31.43 \pm 0.92$ & $5.94 \pm 0.26$ & $1.39 \pm 0.05$ & $0.52 \pm 0.08$ & $3.26 \pm 0.52$ & 3.22 \\
\hline
\end{tabular}

* Data are means \pm S.E.M., $\mathrm{n}=10$ animals/group, treated for seven days by intraperitoneal route. Positive and negative controls were treated by 5 -Flouoruracil ( 5 -FU) and saline $0.9 \%$, respectively. ${ }^{\mathrm{P}}<0.01$ compared to control by ANOVA followed by Newman-Keuls test.

Herein, we also reported the antitumor activity of organic extracts (ethyl acetate, acetone and methanol) obtained from C. procera stem in mice bearing Sarcoma 180 tumor. Sarcoma 180 is a mouse-derived tumor very exploited in antitumor research in vivo (Sato et al. 2005, Magalhães et al. 2006). The effects of the ethyl acetate, acetone and methanol extracts on tumor growth are described in Table III. A significant reduction in tumor weight $(\mathrm{P}<0.01)$ was found at $250 \mathrm{mg} / \mathrm{kg} /$ day in both ethyl acetate- and acetone-treated animals $(1.40 \pm 0.35 \mathrm{~g}$ and $1.34 \pm 0.22 \mathrm{~g}$, respectively) in comparison with negative control $(3.25 \pm 0.47 \mathrm{~g})$, leading to tumor growth inhibition ratios of 64.3 and $53.1 \%$, respectively. The dose of $50 \mathrm{mg} / \mathrm{kg} /$ day reduced tumor weight in $96.5 \%$ in 5-FU-treated mice. In contrast, methanol extract was unable to avoid tumor augmentation within identical experimental conditions.

The mice intraperitoneal treatment with the extracts was not able to interfere on the final body weight and in relative liver, kidneys and spleen weights of the experimental groups (Table III) when compared to negative control ( $P>0.05)$. Moreover, neither mortality nor morbidity were recorded during the whole experiment.

Tumor morphological examination of the control group showed large and polygonal cells, with pleomorphic shapes, hyperchromatic nuclei, binucleation, mitosis and muscle invasion (Fig. 1A). Meanwhile, tumors excised from mice treated with 5-FU, ethyl acetate and acetone extracts exhibited extensive areas of coagulative necrosis alternated with pleormorphic cells (Figs. 1B, 1C and 1D).

Hepatic histopathological analysis of ethyl acetate-, acetone- and methanol-treated animals revealed Kupf- fer cell hyperplasia, ballooning degeneration of hepatocytes, portal tract and centrolobular venous congestion and discrete microvesicular steatosis, though no areas of necrosis were observed (Figs. 2C, 2D and 2E). Focal infiltrate of inflammatory cells was more evident in the methanol group. Regarding kidneys, it was observed glomerular and tubular hemorrhage and hydropic changes of the proximal tubular ephitelium in ethyl acetate- and acetone-treated groups (Figs. 3C and 3D, respectively), but the glomerular structure was essentially preserved. On the other hand, methanolic group did not present kidney alterations while 5-FU group presented hyaline cylinders (Fig. 3B). There was a considerable hyperplasia of the splenic white pulp and megakaryocytes in all treated groups in comparison to the negative control (data not shown), a result possibly caused by substances found in the extracts. In fact, ethanolic extracts of flowers, buds and roots of C. procera contain alkaloids, phenolic compounds/tannins, saponins and lectins, which may have immunomodulatory properties (Imboden 1988, Mossa et al. 1991, Melo et al. 2001, Ferreira et al. 2007, 2009).

The kidney and liver have been proposed as the major key organs to metabolize environmental toxic substances. Due to the good liver regeneration capacity, even when necrosis is found with conjunctive tissue preservation, generally there was a complete hepatic restoration (Kumar et al. 2004). Portal tract and centrolobular venous congestion were also visualized in the control group, suggesting that these effects are related to the hepatocyte metabolism (Scheuer and Lefkowitch 2000). Meanwhile, Kupffer cell hyperplasia and macrovesicular steatosis indicate a presence of a harmful agent 

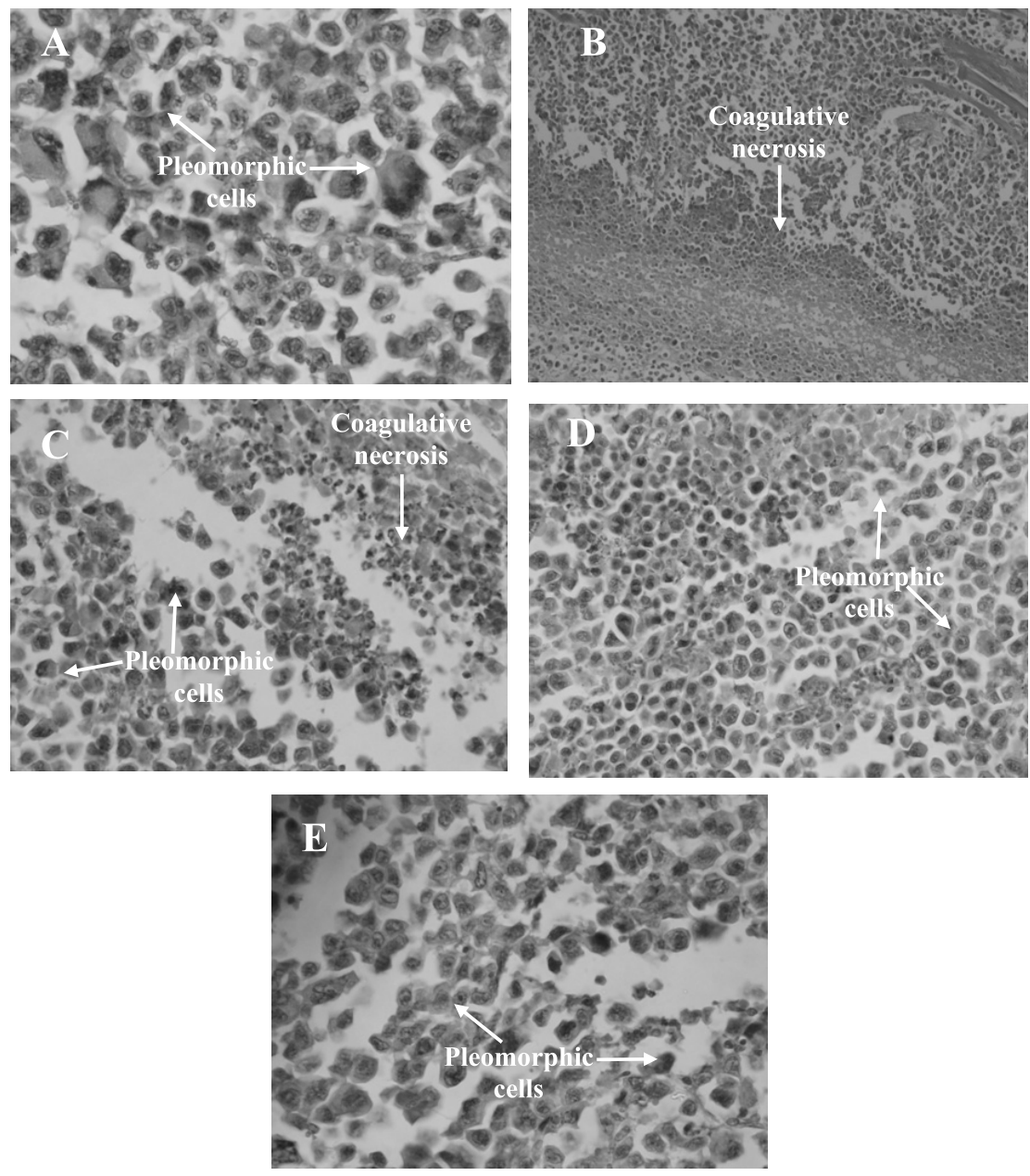

Fig. 1 - Histopathology of tumors excised from Sarcoma 180 transplanted mice after 7 days of intraperitoneal treatment with Calotropis procera stem extracts at the dose of $250 \mathrm{mg} / \mathrm{kg} /$ day (C - ethyl acetate; D - acetone; E - methanol). Negative control (A) and positive control (B) received $0.9 \%$ saline and $5-\mathrm{FU}(50 \mathrm{mg} / \mathrm{kg} /$ day $)$, respectively. Magnification, $400 \times$.

(Kumar et al. 2004), as seen in 5-FU-treated mice. Although all alterations observed in liver and kidneytreated animals were considered reversible, the kidneys should be the target organ of the ethyl acetate and acetone extracts. Nevertheless, the reversible character of injuries proposes that treatment removal leads to quick improvement (Scheuer and Lefkowitch 2000). Melo et al. (2001) showed that goats subcronically fed with pulverized dehydrated aerial parts of C. procera (leaves and twigs) did not undergo suggestive biochemical modifications of liver damage, which could explain the light hepatotoxicity in the face of the dose administered $(250 \mathrm{mg} / \mathrm{kg})$. Safety evaluation studies revealed that ethanolic extracts of aerial parts in single high doses (up to $3 \mathrm{~g} / \mathrm{kg}$ ) do not produce any visible toxic symptoms or mortality, while extended treatment (90 days) causes significantly higher toxicity (Mossa et al. 1991).

The present work shows that ethyl acetate, acetone and methanol stem extracts from $C$. procera possess promising in vitro antiproliferative activity on cancer lines and sea urchin eggs. Meanwhile, ethyl acetate and acetone extracts are able to reduce in vivo tumor growth of Sarcoma 180 transplanted mice in the presence of liver and kidneys reversible toxic effects. Some investigations are in progress in order to identify C. procera cytotoxic compound(s) and to understand the mechanism of action responsible for this tumor-decreasing potential. 

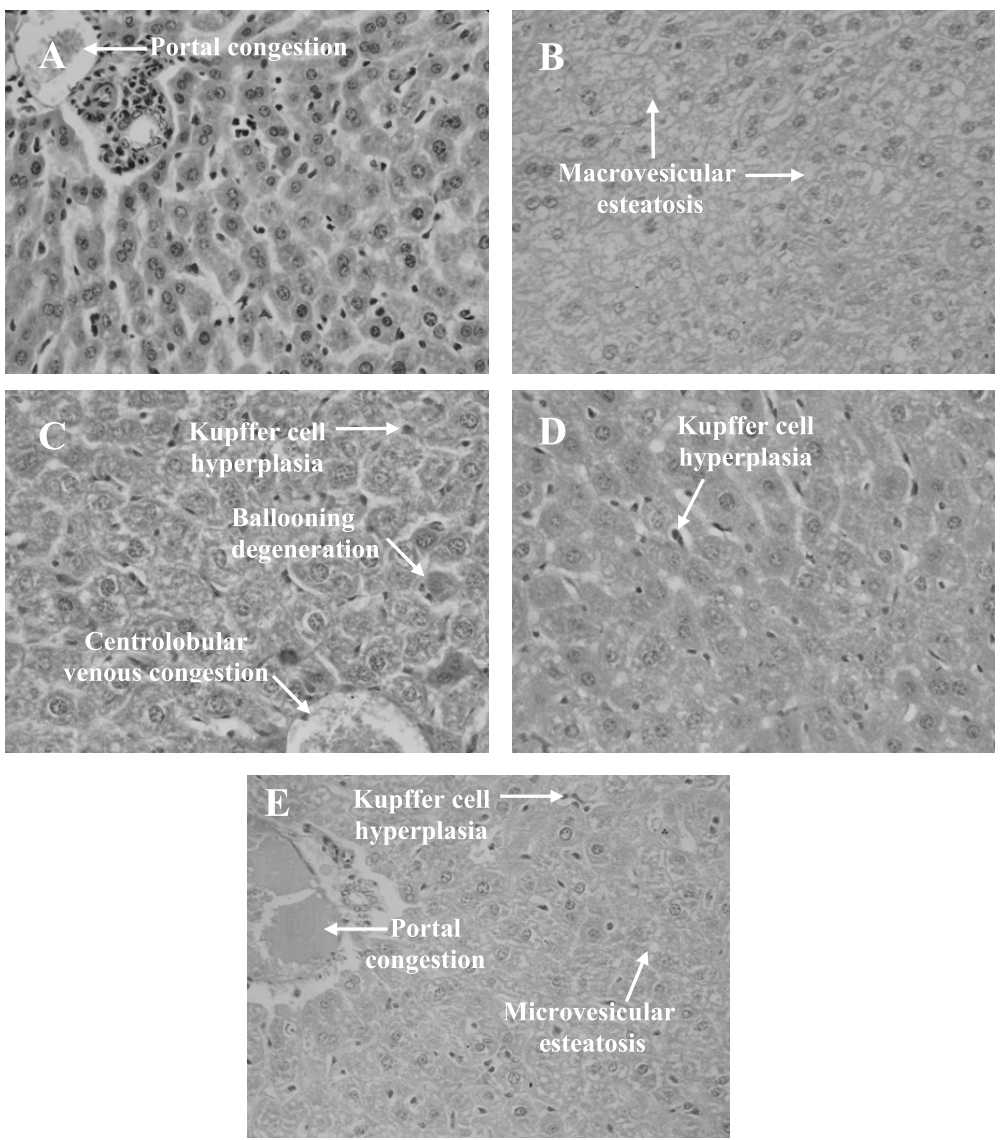

Fig. 2 - Histopathology of livers excised from Sarcoma 180 transplanted mice after 7 days of intraperitoneal treatment with Calotropis procera stem extracts at the dose of $250 \mathrm{mg} / \mathrm{kg} /$ day (C - ethyl acetate; D - acetone; E - methanol). Negative control (A) and positive control (B) received $0.9 \%$ saline and $5-\mathrm{FU}(50 \mathrm{mg} / \mathrm{kg} / \mathrm{day})$, respectively. Magnification, $400 \times$.

\section{ACKNOWLEDGMENTS}

We wish to thank Conselho Nacional de Desenvolvimento Científico e Tecnológico (CNPq), Coordenação de Aperfeiçoamento de Pessoal de Nível Superior (CAPES), Fundação Cearense de Apoio ao Desenvolvimento Científico e Tecnológico (FUNCAP), Financiadora de Estudos e Projetos (FINEP), Banco do Nordeste do Brasil (BNB) and Instituto Claude Bernard ( $\mathrm{InCb}$ ) for financial support in the form of grants and fellowship awards. We are grateful to Silvana França dos Santos and Fátima Texeira for technical assistance.

\section{RESUMO}

O potencial citotóxico de extratos orgânicos do caule de Calotropis procera (Asclepiadaceae) foi primeiramente avaliado frente a linhagens de células tumorais através do ensaio de MTT. Aquelas amostras consideradas citotóxicas foram sub- sequentemente testadas para atividade antimitótica sobre o desenvolvimento de ovos de ouriço-do-mar e para atividade antiproliferativa in vivo em camundongos transplantados com tumor Sarcoma 180. Dentre os cinco extratos estudados (hexano, diclorometano, acetato de etila, acetona e metanol), os extratos acetato de etila e acetona mostraram maior potencial citotóxico contra células tumorais, com $\mathrm{CI}_{50}$ variando de 0,8 to $4,4 \mu \mathrm{g} / \mathrm{mL}$, enquanto o extrato metanólico revelou ser fracamente citotóxico. Os extratos citotóxicos também exibiram capacidade de inibição da divisão celular com valores de $\mathrm{CI}_{50}$ menores que $5 \mu \mathrm{g} / \mathrm{mL}$. Nas avaliações antitumorais in vivo, os animais tratados com os extratos acetato de etila e acetona mostraram taxas de inibição do crescimento tumoral de 64,3 e $53,1 \%$, respectivamente, com efeitos tóxicos reversíveis sobre o fígado e os rins.

Palavras-chave: atividade antimitótica, antiproliferativa, $\mathrm{Ca}$ lotropis procera, Sarcoma 180, extratos de caule. 

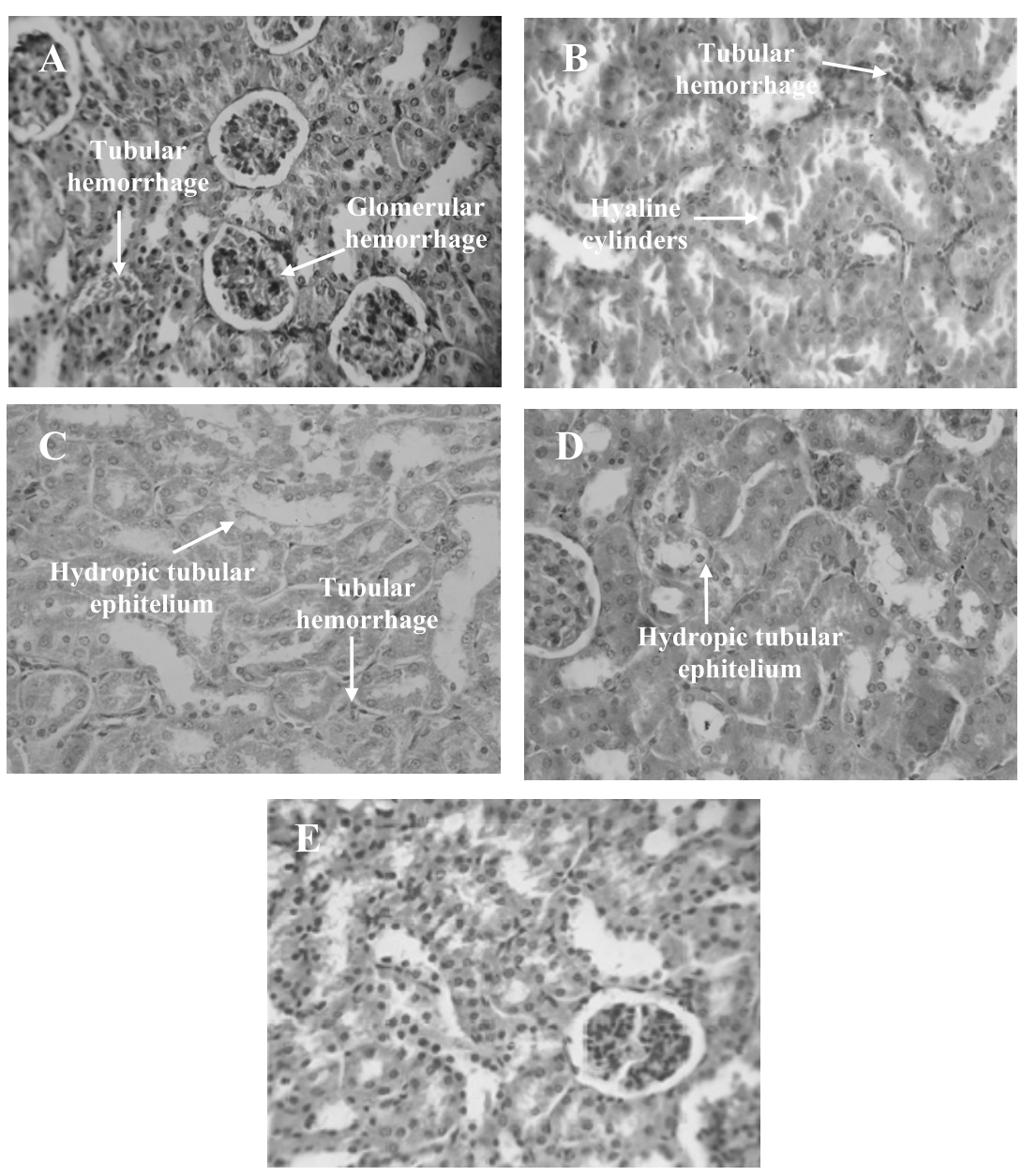

Fig. 3 - Histopathology of kidneys excised from Sarcoma 180 transplanted mice after 7 days of intraperitoneal treatment with Calotropis procera stem extracts at the dose of $250 \mathrm{mg} / \mathrm{kg} / \mathrm{day}$ (C - ethyl acetate; D - acetone; E - methanol). Negative control (A) and positive control (B) received $0.9 \%$ saline and $5-\mathrm{FU}(50 \mathrm{mg} / \mathrm{kg} / \mathrm{day})$, respectively. Magnification, $400 \times$.

\section{REFERENCES}

Ahmed MKK, Rana AC And Dixit VK. 2003. Free radical scavenging activity of Calotropis species. Indian Drugs 40: 654-655.

AlEnCAR NMN, Oliveira JS, Ribeiro RA AND RAMOS MV. 2004. Anti-inflammatory effect of the latex from Calotropis procera in three different experimental models: Peritonitis, Paw edema and Hemorrhagic cystitis. Planta Med 70: 1144-1149.

BRANDHORST PB. 1985. Informational content of the echinoderm egg. In: BROWDER LW (Ed), Development Biology, a Comprehensive Synthesis Oogenesis, New York: Plenum Press, p. 525-576.

Buriol L ET AL. 2009. Composição química e atividade biológica de extrato oleoso de própolis: uma alternativa ao extrato etanólico. Quim nova 32: 296-302.
Choedon T, Mathan G, Arya S, Kumar VL And KUMAR V. 2006. Anticancer and cytotoxic properties of the latex of Calotropis procera in a transgenic mouse model of hepatocellular carcinoma. World J Gastroenterol 12: 2517-2522.

Costa PM, Ferreira PMP, Bolzani VS, Furlan M, SAntos VAFFM, CORSINO J, MORAES MO, COSTALotufo LV, Montenegro RC And Pessoa C. 2008. Antiproliferative activity of pristimerin isolated from Maytenus ilicifolia (Celastraceae) in human HL-60 cells. Toxicol in vitro 22: 854-863.

Cragg GM And Newman DJ. 2005. Plants as a source of anti-cancer agents. J Ethnopharmacol 100: 72-79.

Dewan S, Kumar S And Kumar VL. 2000. Antipyretic effect of latex of Calotropis procera. Indian J Pharmacol 32: 252 . 
Dieye AM, Tidjani MA, Diouf A, Bassene E And FAYE B. 1993. Senegalese pharmacopoeia: study of acute toxicity and antitussive activity of Calotropis procera AIT (Asclepiadaceae). Dakar Med 38: 69-72.

EEC Directive of 1986. Council Directive of 24 November 1986 on the approximation of laws, regulations and administrative provisions of the Member States regarding the protection of animals used for experimental and other scientific purposes $(86 / 609 / \mathrm{EEC})$.

FErreira PMP, CARVAlHo AFFU, Sousa DF, MAGAlhães JF, MARTins AR, MARTINS MAC AND QUEIROZ MGR. 2007. Water extract of Moringa oleifera seeds: a toxicological approach. REPM 1: 45-57.

FERreira PMP, FARIAs DF, Oliveira JTA AND CARVALHO AFFU. 2008. Moringa oleifera: Bioactive compounds and nutritional potential. Rev Nutr 21: 431-437.

FERreira PMP, CARVAlHo AFFU, FARIAs DF, CARIOLANo NG, MElo VMM, Queiroz MGR, Martins AMC AND MACHADO-NETO JG. 2009. Larvicidal activity of the water extract of Moringa oleifera seeds against Aedes aegypti and its toxicity upon laboratory animals. An Acad Bras Cienc 81: 207-216.

IMBODEN JB. 1988. The regulation of intracellular signals during lymphocyte activation. Immunol Today 9: 17-18.

IQBAL Z, LATEEF M, JABBAR A, MUhammad G AND KHANA MN. 2005. Anthelmintic activity of Calotropis procera (Ait.) Ait. F. flowers in sheep. J Ethnopharmacol 102: 256-261.

JACOBS RS AND WILSON L. 1986. Fertilized sea urchin egg as a model for detecting cell division inhibitors. In: Aszalor A (Ed), Modern analysis of antibiotics, New York, Marcel Dekker, Inc., p. 481-493.

JAIN SC, Sharma R, JAIN R AND ShaRma RA. 1996. Antimicrobial activity of Calotropis procera. Fitoterapia 67: 275-277.

Kamath JV And Rana AC. 2002. Preliminary study on antifertility activity of Calotropis procera roots in female rats. Fitoterapia 73: 111-115.

Kissmann KG And Groth D. 1999. Plantas infestantes e nocivas, São Paulo, Editora BASF, 523 p.

Kumar V, Abbas AK, Fausto N, Robbins SL And Cotran RS. 2004. Pathology Basis of Disease. China: WB Saunders, $1552 \mathrm{p}$.

KUMAR VL AND BASU N. 1994. Anti-inflammatory activity of the latex of Calotropis procera. J Ethnopharmacol 44: $123-125$.
KUMAR VL AND SHIVKAR YM. 2004. In vivo and in vitro effect of latex of Calotropis procera on gastrointestinal smooth muscles. J Ethnopharmacol 93: 377-379.

Kurosawa M, TANi Y, Nishimura S, Numazawa S AND YoshidA T. 2001. Distinct PKC isozymes regulate bufalin-induced differentiation and apoptosis in human monocytic cells. Am J Physiol Cell Physiol 280: 459-464.

LEFRANC F ET AL. 2008. Targeting the alpha 1 subunit of the sodium pump to combat glioblastoma cells. Neurosurgery 62: 211-221.

Lorenzi H And Matos FJA. 2002. Plantas medicinais no Brasil: nativas e exóticas. São Paulo, Instituto Plantarum, $544 \mathrm{p}$.

Magalhães Hif, Veras ML, Torres Mr, Alves APNN, Pessoa OdL, Silveira ER, Costa-Lotufo LV, Moraes MO AND PessoA C. 2006. In vitro and in vivo antitumor activity of physalins $\mathrm{B}$ and $\mathrm{D}$ from Physalis angulata. J Pharm Pharmacol 58: 235-241.

Mahmoud OM, Haroun EM, SOBAIH MA, OMEr OH AND ADAM SEI. 2001. Comparative efficacy of Calotropis procera latex and sulfadimidine against experimentally-induced Eimeria ovinoidalis infection in Najdi lambs. Small Ruminant Res 42: 135-140.

MaiUri MC, Zalckvar E, Kimchi A And Kroemer G. 2007. Self-eating and self-killing: crosstalk between autophagy and apoptosis. Nat Rev Mol Cell Biol 8: 741-752.

Mascolo N, Sharma R, JAIn SC AND CAPASSo FJ. 1988. Ethnopharmacololgy of Calotropis procera flowers. J Ethnopharmacol 22: 211-221.

MCCONKEy DJ, Lin Y, NutT LK, OZEL HZ AND NeWMAN RA. 2000. Cardiac glycosides stimulate $\mathrm{Ca}^{2+}$ increases and apoptosis in androgen-independent, metastatic human prostate adenocarcinoma cells. Cancer Res 60: 3807-3812.

Melo MM, Vaz FA, Gonçalves LC And SATURnino HM. 2001. Estudo fitoquímico da Calotropis procera Ait., sua utilização na alimentação de caprinos: efeitos clínicos e bioquímicos séricos. Rev Bras Saúde Prod An 2: 15-20.

Moreira DRM, Leite ACL, Ferreira PMP, Costa PM, Costa-Lotufo LV, Moraes MO, Brondani DJ AND PESSOA C. 2007. Synthesis and antitumour evaluation of peptidyl-like derivatives containing the 1,3benzodioxole system. Eur J Med Chem 42: 351-357.

MOSMAnN T. 1983. Rapid colorimetric assay for cellular growth and survival: application to proliferation and cytotoxicity assays. J Immunol Methods 16: 55-63. 
Mossa JS, Tariq M, Mohsin A, Ageel AM, Al-Yahya MA, Al-Said MS and Rafatullah S. 1991. Pharmacological studies on aerial parts of Calotropis procera. Am J Chin Med 19: 223-231.

OLIVEIRA JS, BEZERRA DP, FREITAS CDT, FILHO JDBM, Moraes MO, Pessoa C, Costa-Lotufo LV And RAMOS MV. 2007. In vitro cytotoxicity against different human cancer cell lines of laticifer proteins of Calotropis procera (Ait.) R. Br. Toxicol in vitro 21: 15631573.

RAmos MV, BANDEIRA GP, Freitas CDT, NOGUEIRA NAP, AlEnCAR NMN, Sousa AS AND CARvalho AFU. 2006. Latex constituents from Calotropis procera (R. Br.) display toxicity upon egg hatching and larvae of Aedes aegypti (Linn.). Mem Inst Oswaldo Cruz 101: 503-510.

Roy S, Sehgal R, Padhy BM and Kumar VL. 2005. Antioxidant and protective effect of latex of Calotropis procera against alloxan-induced diabetes in rats. J Ethnopharmacol 2: 470-473.

Sato DYo, Wal R, DE Oliveira CC, CATtaneo RiI, Malvezzi M, Gabardo J AND BUCHI DF. 2005. Histopathological and immunophenotyping studies on normal and sarcoma 180-bearing mice treated with a complex homeopathic medication. Homeopathy 94: 26-32.

Satyavati GV, RAinA MK And Sharma M. 1976. Medicinal plants of India. New Delhi, CMR, 19 p.
SCheuer PJ AND LefKowitch JH. 2000. Drugs and Toxins. In: ScheUER PJ AND LeFKOWITCH JH (Eds), Liver Biopsy Interpretation, London: WB Saunders, p. $134-150$.

Setty SR, QUereshi AA, SWAMY AHMV, PATIL T, PraKASH T, PRABHU K AND GoudA AV. 2007. Hepatoprotective activity of Calotropis procera flowers against paracetamol-induced hepatic injury in rats. Fitoterapia 78: $451-454$.

SHARMA P AND SHARMA JD. 2000. In vitro schizonticidal screening of Calotropis procera. Fitoterapia 71: 77-79.

Smit HF, Woerdenbag HJ, Singh RH, Meulenbeld GJ, LABADIE RP AND Zwaving JH. 1995. Ayurvedic herbal drugs with possible cytostatic activity. JEthnopharmacol 47: 75-84.

Suffness M And Pezzuto JM. 1990. Assays related to cancer drug discovery. In: Hostettmann K(Ed), Methods in plant biochemistry: assays for bioactivity, London: Academic Press, p. 71-133.

Van Quaquebeke E, Simon G, Dewelle AJ, Yazidi Me, Bruynaeel F, Tuti J, Nacoulma O, Guissou P, DECAESTECKER BJC AND KISS RF. 2005. Identification of a novel cardenolide ( $2{ }^{\prime \prime}$-Oxovoruscharin) from Calotropis procera and the hemisynthesis of novel derivatives displaying potent in vitro antitumor activities and high in vivo tolerance: structure-activity relationship analyses. J Med Chem 48: 849-856. 